\title{
Clinical and blood gas analysis of calves conceived by artificial insemination, in vitro fertilization and animal cloning ${ }^{1}$
}

\author{
Gabriela N. Dantas²* (D), Bianca P. Santarosa² (D), Fernando J. Benesi ${ }^{3}$, \\ Vitor Hugo Santos ${ }^{2}$ and Roberto C. Gonçalves ${ }^{2}$
}

\begin{abstract}
Dantas G.N., Santarosa B.P., Benesi F.J., Santos V.H. \& Gonçalves R.C. 2019. Clinical and blood gas analysis of calves conceived by artificial insemination, in vitro fertilization and animal cloning. Pesquisa Veterinária Brasileira 39(7):485-491. Faculdade de Medicina Veterinária e Zootecnia, Universidade Estadual Paulista, Campus de Botucatu, Distrito de Rubião Júnior s/n, Botucatu, SP 18618-970, Brazil. E-mail: gabrielan.dantas@gmail.com

In order for successful extra-uterine adaptation to occur, it is necessary for the neonate to be able to establish its respiratory functions effectively, guaranteeing efficient oxygenation and good vitality. Respiratory disorders are the major cause of death during the neonatal period in cattle, and this mortality is even more significant when it comes to calves originated by in vitro fertilization (FIV) or animal cloning (CA). Blood gas analysis assesses acid-base balance changes effectively, and when associated with the neonate's clinical examination, provides subsidies for accurate diagnosis and early treatment of neonatal maladaptation. The objective of this study was to study neonates born from artificial insemination (IA) and to compare them to calves conceived by FIV and CA, regarding blood gas and clinical examination. For that, 20 AI calves, 15 FIV calves, and 15 cloned calves were evaluated immediately after calving and at 6, 12, 24 and 48 hours of life. At all experimental times, venous blood samples were collected for blood gas and clinical examination was performed. In the postpartum evaluation, Apgar score and column length and respiratory amplitude measurements were used. IVF animals showed no alterations, resembling Group IA calves. The calves from CA showed more pronounced acidosis postpartum than expected physiological acidosis mixed for neonates, with decreasing values of bicarbonate $\left(\mathrm{HCO}_{3}^{-}\right)$, and base excess (BE) and the increase in carbon dioxide pressure $\left(\mathrm{PCO}_{2}\right)$ when compared to the other groups. This disorder may have reflected lower mean values of Apgar scores and increased heart and respiratory rates. Intensive follow-up of these neonates is suggested, with monitoring by clinical and hemogasometric examination for early diagnosis of this condition and treatment based on oxygen therapy and bicarbonate replacement.
\end{abstract}

INDEX THERMS: Clinics, blood gas, calves, analysis, artificial insemination, vitro fertilization, animal cloning, apgar score, cattle, neonatology, respiratory acidosis, respiratory amplitude.

\footnotetext{
${ }^{1}$ Received on February 16, 2019.

Accepted for publication on April 01, 2019.

Part of the Doctoral Dissertation of the first author. Financed by "Fundação de Amparo à Pesquisa do Estado de São Paulo" (FAPESP) through scholarship (Proc. 2014/26041-8).

${ }^{2}$ Faculdade de Medicina Veterinária e Zootecnia (FMVZ), Universidade Estadual Paulista (Unesp), Campus de Botucatu, Distrito de Rubião Júnior s/n, Botucatu, SP 18618-970, Brazil. *Corresponding author: gabrielan.dantas@gmail.com

${ }^{3}$ Faculdade de Medicina Veterinária e Zootecnia (FMVZ), Universidade de São Paulo (USP), Av. Prof. Orlando Marques de Paiva 87, Butantã, São Paulo, SP 05508-010, Brazil.
}

RESUMO.- [Análise clínica e hemogasométrica de bezerros concebidos por inseminação artificial, fertilização in vitro e clonagem animal.] Para que ocorra adaptação extra-uterina bem sucedida é necessário que o neonato consiga estabelecer suas funções respiratórias de maneira eficaz, garantindo oxigenação eficiente e boa vitalidade. Distúrbios respiratórios são os maiores causadores de óbito durante o período neonatal em bovinos, e essa mortalidade é ainda mais expressiva quando se trata de bezerros originados por fertilização in vitro (FIV) ou clonagem animal (CA). A hemogasometria avalia alterações do equilíbrio ácido-básico de forma eficaz, 
e quando associada ao exame clínico do neonato, fornece subsídios para diagnóstico acurado e tratamento precoce da má adaptação neonatal. 0 objetivo deste trabalho foi estudar recém-nascidos bovinos originados por inseminação artificial (IA) e compará-los a bezerros concebidos por FIV e CA, no que se refere a hemogasometria e exame clínico. Para isso, foram utilizados 20 bezerros IA, 15 bezerros FIV e 15 bezerros clonados que foram avaliados imediatamente após o parto e com 6, 12, 24 e 48 horas de vida. Em todos os momentos experimentais foram colhidas amostras de sangue venoso para hemogasometria e foi realizado o exame clínico. Na avaliação pós-parto foram utilizados escore Apgar e mensurações de comprimento de coluna e amplitude respiratória. Os animais FIV não demonstraram alterações, assemelhando-se aos bezerros do Grupo IA. Os bezerros provenientes de CA apresentaram acidose pós-parto mais acentuada do que a acidose mista fisiológica esperada para neonatos, evidenciada pela diminuição dos valores de bicarbonato $\left(\mathrm{HCO}_{3}^{-}\right)$e excesso de bases (EB) e pelo aumento de pressão parcial de dióxido de carbono $\left(\mathrm{PCO}_{2}\right)$ quando comparados aos demais grupos. Esse distúrbio pode ter refletido em valores médios menores de escore Apgar e no aumento das frequências cardíaca e respiratória. Sugere-se acompanhamento intensivo desses neonatos, com monitoramento por meio do exame clínico e hemogasométrico para diagnóstico precoce dessa condição e tratamento baseado em oxigenioterapia e reposição de bicarbonato.

TERMOS DE INDEXAC̄̃̃O: Clínica, hemogasometria, bezerros, inseminação artificial, fertilização in vitro, clonagem animal, acidose respiratória, amplitude respiratória, bovinos, escore Apgar, neonatologia.

\section{INTRODUCTION}

Most of the advances in newborn animal health care in the last decades concern respiratory function. As one of the main causes of perinatal mortality in bovines, it is essential for adaptation and survival of neonates outside the uterus (Mee 2008, Bleul 2009). Animals born after in vitro fertilization (IVF) and animal cloning (AC), alongside premature neonates, are more likely to present respiratory conditions. Birgel Junior et al. (2011) observed a high incidence of neonatal asphyxia leading to death in cloned calves. Thus, proper respiratory adaptation resulting in efficient body oxygenation and good vitality is a crucial factor for the survival of these newborns.

In order to evaluate this process, blood gas analysis shows useful data on acid-base balance, which supports diagnosis and prognostics of several diseases affecting cattle (Sucupira \& Ortolani 2003). In neonates, after cutting the umbilical cord and during the transition from placental to pulmonary oxygenation, minor transient respiratory and metabolic acidosis is observable due to the anaerobic glycolysis in low-perfused tissues (Vaala \& House 2006). This condition is aggravated by neonates' reduced breathing capacity, characterized by hypoventilation, which hinders the efficiency of carbon dioxide $\left(\mathrm{CO}_{2}\right)$ removal, increases the production of carbonic acid, and consequently reduces blood pH (Benesi 1993, Piccione et al. 2006). To fight acid-base imbalance, the organism usually adopts the following mechanisms: chemical buffering with bicarbonate, ventilation adjustment, and renal excretion of ions. The buffer and respiratory systems act within a few minutes, while the kidneys are slow to respond to acid or base excess (Houpt 2006).

Venous blood is commonly used for blood gas analysis, as it is easier to collect than arterial blood and provides reliable results in cases of metabolic acidosis (Dibartola 1992). Sucupira \& Ortolani (2003) found a high correlation among the $\mathrm{pH}$, bicarbonate $\left(\mathrm{HCO}_{3}^{-}\right)$, and base excess (BE) values between venous and arterial blood in cattle, which indicates that venous blood may accurately reflect acid-base balance.

Clinical examination is also key to evaluate newborns in addition to the blood gas analysis (Feitosa \& Benesi 2014). Following birth, the Apgar score evaluates head movement, reflexes, type of respiration, and mucosal color to identify newborns with vitality changes (Born 1981). Additionally, vital signs such as heart (HR) and respiratory rate (RR) and rectal temperature (RT) must be measured (Feitosa \& Benesi 2014). The breath amplitude (BA) measure, which reflects rib cage expansion, may provide useful information on the calves' pulmonary compliance and ability to effectively ventilate. Furthermore, the size of the newborn may help or hinder birth, besides indicating fetal maturity, which makes spine length (SL) another useful measure to complement neonatal evaluation (Dantas 2015).

Given the above, this work aimed to study calves conceived by artificial insemination (AI), a more simple and common technique with regard to blood gas analysis and clinical examination, comparing them to newborns conceived by IVF and $\mathrm{AC}$ to evaluate if the latter are more prone to acid-base balance changes, which translates into worse neonatal respiratory adaptation. These cases require clinical intervention to ensure the animals' health and reduce high mortality rates associated with this category of newborns.

\section{MATERIALS AND METHODS}

Animals. A total of 50 neonates was used in this study: 20 calves from artificial insemination (Group AI, all male), 15 calves from in vitro fertilization (Group IVF, 11 females and four males), and 15 cloned calves (AC Group, 10 females and five males). The animals in the AI Group were obtained from a farm located in Descalvado, state of São Paulo; the IVF Group, from a farm in Santa Rita de Caldas, state of Minas Gerais; and the AC Group, from a commercial enterprise located in Mogi-Mirim, São Paulo. As to their breed, the neonates in the AI and IVF groups were black and white Holsteins (BWH) born by vaginal delivery, while the AC Group was composed of five BWH, five Gir, and five Nelore calves born by C-section. The deliveries, which took place in calving pens or paddocks, were followed-up. The animals were evaluated as to health and maturity, and those presenting severe health conditions or requiring treatment were excluded. All of the cows were kept in a semi-intensive regime, with access to feeding trough containing corn silage and to pasture, in addition to water ad libitum and the concentrated feed used in each farm. The study included cows with body condition scores between three and four (Feitosa \& Benesi 2014); unhealthy calves were excluded. After birth, the calves were separated from their mothers and bottle-fed, having received their colostrum until 48 hours after birth. The experiment was carried out from July 2015 to December 2016.

Ethical aspects. This study has been approved by the Animal Research Ethics Committee (CEUA) of "Faculdade de Medicina Veterinária e Zootecnia" (FMVZ) of the "Universidade Estadual Paulista” (Unesp), Botucatu campus, under protocol number 197/2014. 
Clinical and blood gas analyses. All calves were followed-up from birth to 48 hours after birth. At one minute postpartum (PP), the neonate Apgar score was measured according to a scale modified by Born (1981). Within the first PP time points, measurements were also taken, with the aid of a measuring tape, of the spine length from the atlanto-occipital joint to the first coccygeal vertebra - and breath amplitude reflecting the rib cage expansion of the neonates. These measurements were taken while the animals were still in decubitus position, and the chest circumference was obtained from the thirteenth rib at the end of inspiration, i.e. at maximum expansion. Within the first five minutes of life, the heart and respiratory rate and rectal temperature were also evaluated in accordance with the semiological methods recommended by Feitosa \& Benesi (2014). This physical examination was repeated at all experimental time points, namely: at birth, 6, 12, 24, and 48 hours PP, when venous blood was also collected for blood gas analysis by means of puncturing the jugular vein of the neonates with a $30 \times 10$ needle coupled to a heparinized $1 \mathrm{~mL}$ syringe. The sample for blood gas analysis was processed immediately after collection in a portable $\mathrm{pH}$, electrolyte, and blood gas analyzer (I-STAT ${ }^{\circledR}$, Abbott Laboratories, Illinois, USA). CG7+ cartridges (I-STAT ${ }^{\circledR}$, Abbott Laboratories, Illinois, USA) were used to measure $\mathrm{pH}$, partial pressures of oxygen and carbon dioxide $\left(\mathrm{PPO}_{2}\right.$ e $\left.\mathrm{PPCO}_{2}\right)$, oxygen saturation $\left(\mathrm{SO}_{2}\right)$, bicarbonate $\left(\mathrm{HCO}_{3}\right)$, total carbon dioxide $\left(\mathrm{TCO}_{2}\right)$, and base excess (BE) with temperature correction.

Statistical analysis. A One-Way Repeated Measures Anova was carried out for comparison of the evaluation times individually within each group. An analysis of variance was also carried out at each time to compare the study groups $(\mathrm{P}<0.05)$. When significance was found $(\mathrm{P}<0.05)$, the Tukey Test was applied for comparison of means $(\mathrm{P}<0.05)$. A non-parametric analysis was chosen only for the BE data, which did not present Gaussian distribution. The Friedman test (Repeated Measures) was carried out for comparison of the evaluation times individually within each group. When significance was found $(\mathrm{P}<0.05)$, the Tukey Test was applied for comparison of medians $(\mathrm{P}<0.05)$. The Kruskal-Wallis test was also carried out at each time point to compare the study groups $(\mathrm{P}<0.05)$.

\section{RESULTS AND DISCUSSION}

Tables 1 to 11 present the results obtained from clinical examination and blood gas analysis of the calves in the different groups.

The first analysis, carried out immediately after birth, was the Apgar score (Table 1), which aimed at determining the animals' vitality. All of the 50 neonates evaluated in this study

Table 1. Apgar score, breath amplitude (BA), and spine length (SL) of the groups of calves conceived by artificial insemination (AI), in vitro fertilization (IVF), and animal cloning (AC) at birth (0-hour time point)

\begin{tabular}{cccc}
\hline \multirow{2}{*}{ Groups } & \multicolumn{3}{c}{ 0-hour time point } \\
\cline { 2 - 4 } & Apgar & BA (cm) & SL (cm) \\
\hline AI & $7.9 \pm 0.3 \mathrm{a}$ & $73.2 \pm 5.5 \mathrm{~b}$ & $88.0 \pm 8.0 \mathrm{a}$ \\
IVF & $7.7 \pm 0.4 \mathrm{a}$ & $81.7 \pm 3.6 \mathrm{a}$ & $92.4 \pm 4.9 \mathrm{a}$ \\
$\mathrm{AC}$ & $7.3 \pm 0.6 \mathrm{~b}$ & $82.1 \pm 1.9 \mathrm{a}$ & $91.1 \pm 3.7 \mathrm{a}$ \\
$\mathrm{P}$ & 0.001 & $<0.001$ & 0.099
\end{tabular}

Data presented as mean \pm standard deviation. ${ }^{\text {ab }}$ Means followed by the same lower case letter in a column do not differ significantly by the Tukey test $(\mathrm{P}>0.05)$. obtained scores of $7 / 8$ or $8 / 8$, high scores indicating good vitality at birth. This is due to the fact that calves presenting severe health conditions or malformations were excluded from the study, since they did not live for the entire period of 48 hours or required treatment, which would compromise the evaluations. However, it must be noted that the AC Group obtained the lowest mean of Apgar scores, which indicates less vitality at birth compared to the two other groups.

We did not observe differences in size measured by spine length (SL) among the calves (Table 1). Although the literature refers to macrosomia as a common change in cloned animals (Birgel Junior et al. 2011), this study did not identify the syndrome. This may be because the AC Group was composed by neonates from three different breeds, which could dilute variations in SL. The breath amplitude (BA) of the AI calves was lower than the IVF and cloned calves. This may be related to three situations: the animals in the AI Group presented lower breath amplitude with lower lung compliance, which would not be compatible with their clinics, as they did not present signs of neonatal asphyxia; the newborns in the AI Group simply had chests slimmer than the other calves, which naturally presented bigger circumferences for being larger; the IVF and AC groups presented higher BA values due to increased depth and difficult breathing (hyperpnea) as an attempt to compensate for deficient oxygenation. These two last factors would corroborate the tendency of cloned and IVF calves (Pimenta-Oliveira et al. 2011), as they are bigger than AI calves, to present less efficient respiratory adaptation.

The remaining vital signs, HR and RR (Tables 2 and 3) were within the physiological ranges established for neonate calves, with variations (Lisboa et al. 2003, Gasparelli 2007). Nevertheless, a few differences were noted among the groups. The calves in all three groups presented similar HR values at birth, which tended to drop afterwards, whereas differences were found among the groups throughout the evaluation period, at 48 hours, the CA Group reached the highest average of all. It is worth noting that, during the neonatal period, neurological control of the cardiovascular system is partial, since the myocardial sympathetic nerve function is incomplete. Thus, $\mathrm{HR}$ is variable when the animals are under stress caused, for instance, by manipulation (Feitosa \& Benesi 2014). This factor may explain the increased HR in clones, since they were bred in a commercial enterprise with high economic value, they were more closely monitored than the calves in the other groups. In addition, increased HR may be a compensation for low oxygenation caused by neonatal respiratory maladaptation. The RR of the AC Group was also higher at zero, six, and 48 hours, being constantly higher than the other groups. Higher mean RR values are associated with incomplete pulmonary function, which is attributed to a compensation mechanism. High HR means associated to high RR may suggest that the respiratory adaptation of the neonates in Group AC was less efficient (i.e. slower). Therefore, these animals presented high RR as an attempt to revert hypoxia. However, in order to better analyze this hypothesis, the results of the blood gas analyses must be taken into account (Benesi 1993).

There was no difference in rectal temperature (Table 4) among the groups at the first experimental time point. At six hours, Group AI presented lower means, even lower than reference values (Feitosa \& Benesi 2014), indicating a tendency for hypothermia. This may be explained by the inability of 
Table 2. Heart rate (HR) in the groups of calves conceived by artificial insemination (AI), in vitro fertilization (IVF), and animal cloning (AC), at the different time points of the study $(0,6,12,24$, and 48 hours after birth)

\begin{tabular}{|c|c|c|c|c|}
\hline \multirow{2}{*}{ Time points } & \multicolumn{3}{|c|}{ HR (bpm) } & \multirow{2}{*}{$\mathrm{P}$} \\
\hline & $\mathrm{AI}$ & IVF & AC & \\
\hline T0 & $152.6 \pm 35.2 \mathrm{aA}$ & $151.0 \pm 22.0 \mathrm{aA}$ & $140.0 \pm 13.0 \mathrm{abA}$ & 0.377 \\
\hline $\mathrm{T} 6$ & $152.0 \pm 29.8 \mathrm{aA}$ & $135.2 \pm 11.1 \mathrm{aAB}$ & $129.7 \pm 14.9 \mathrm{bB}$ & 0.009 \\
\hline $\mathrm{T} 12$ & $145.1 \pm 20.0 \mathrm{abA}$ & $132.4 \pm 31.2 \mathrm{aA}$ & $149.0 \pm 17.0 \mathrm{aA}$ & 0.129 \\
\hline $\mathrm{T} 24$ & $133.8 \pm 27.2 \mathrm{cA}$ & $134.5 \pm 14.5 \mathrm{aA}$ & $142.0 \pm 8.6 \mathrm{abA}$ & 0.428 \\
\hline $\mathrm{T} 48$ & $133.8 \pm 19.6 \mathrm{cB}$ & $133.9 \pm 16.2 \mathrm{aB}$ & $149.0 \pm 17.2 \mathrm{aA}$ & 0.031 \\
\hline
\end{tabular}

Data presented as mean \pm standard deviation. ${ }^{\mathrm{a}, \mathrm{b}, \mathrm{c}, \mathrm{A}, \mathrm{B}}$ Means followed by the same lower case letter in a column and upper case in a row do not differ significantly by the Tukey test $(\mathrm{P}>0.05)$.

Table 3. Means and standard deviations for respiratory rate (RR) in the groups of calves conceived by artificial insemination (AI), in vitro fertilization (IVF), and animal cloning (AC), at the different test time points $(0,6,12,24$, and 48 hours after birth)

\begin{tabular}{|c|c|c|c|c|}
\hline \multirow{2}{*}{ Time points } & \multicolumn{3}{|c|}{ RR (bpm) } & \multirow{2}{*}{$\mathrm{P}$} \\
\hline & $\mathrm{AI}$ & IVF & $\mathrm{AC}$ & \\
\hline $\mathrm{T} 0$ & $58.4 \pm 14.8 \mathrm{aB}$ & $57.0 \pm 10.0 \mathrm{abB}$ & $73.0 \pm 11.7 \mathrm{aA}$ & 0.001 \\
\hline T6 & $50.6 \pm 15.3 \mathrm{aB}$ & $47.1 \pm 11.1 \mathrm{bB}$ & $62.0 \pm 9.5 \mathrm{abA}$ & 0.005 \\
\hline $\mathrm{T} 12$ & $59.4 \pm 14.4 \mathrm{aA}$ & $49.7 \pm 10.7 \mathrm{bA}$ & $57.7 \pm 14.4 \mathrm{bA}$ & 0.097 \\
\hline $\mathrm{T} 24$ & $58.6 \pm 19.2 \mathrm{aA}$ & $58.4 \pm 20.8 \mathrm{abA}$ & $56.7 \pm 10.3 \mathrm{bA}$ & 0.947 \\
\hline $\mathrm{T} 48$ & $57.6 \pm 15.5 \mathrm{aB}$ & $64.5 \pm 19.4 \mathrm{aAB}$ & $67.30 \pm 7.6 \mathrm{aA}$ & 0.016 \\
\hline $\mathrm{P}$ & 0.141 & 0.007 & $<0.001$ & \\
\hline
\end{tabular}

$\overline{a, b, A, B}$ Means followed by the same lower case letter in a column and upper case in a row do not differ significantly by the Tukey test (P $>0.05$ ).

Table 4. Means and standard deviations for rectal temperature (RT) in the groups of calves conceived by artificial insemination (AI), in vitro fertilization (IVF), and animal cloning (AC), at the different test time points $(0,6,12,24$, and 48 hours after birth)

\begin{tabular}{|c|c|c|c|c|}
\hline \multirow{2}{*}{ Time points } & \multicolumn{3}{|c|}{$\mathrm{RT}\left({ }^{\circ} \mathrm{C}\right)$} & \multirow{2}{*}{$\mathrm{P}$} \\
\hline & $\mathrm{AI}$ & IVF & $\mathrm{AC}$ & \\
\hline T0 & $38.2 \pm 1.2 \mathrm{aA}$ & $38.9 \pm 0.5 \mathrm{abA}$ & $38.8 \pm 0.8 \mathrm{aA}$ & 0.063 \\
\hline $\mathrm{T} 6$ & $37.8 \pm 0.6 \mathrm{aB}$ & $38.6 \pm 0.2 \mathrm{bA}$ & $38.4 \pm 0.7 \mathrm{abA}$ & $<0.001$ \\
\hline $\mathrm{T} 12$ & $38.2 \pm 0.7 \mathrm{aB}$ & $38.6 \pm 0.4 \mathrm{bA}$ & $38.2 \pm 0.4 \mathrm{bAB}$ & 0.036 \\
\hline $\mathrm{T} 24$ & $38.3 \pm 0.5 \mathrm{aA}$ & $38.7 \pm 0.3 \mathrm{bA}$ & $38.5 \pm 0.6 \mathrm{abA}$ & 0.111 \\
\hline $\mathrm{T} 48$ & $38.4 \pm 0.8 \mathrm{aB}$ & $39.1 \pm 0.5 \mathrm{aA}$ & $38.8 \pm 0.5 \mathrm{aAB}$ & 0.006 \\
\hline
\end{tabular}

$\overline{a, b, A, B}$ Means followed by the same lower case letter in a column and upper case in a row do not differ significantly by the Tukey test (P $>0.05$ ).

neonates to maintain their body temperature under adverse conditions, once this experimental stage took place in wintertime and in a geographical region with low temperature means. Over time, their temperatures normalized; at 24 hours, the means of the three groups were similar.

Lisboa et al. (2002) carried out a study evaluating the effect of age on the acid-base balance of healthy female calves during their first month of life. For such, the authors used venous blood specimens of 300 female BWH calves distributed among several age groups. These groups included neonates whose blood was collected up to eight hours PP (corresponding to the zero and six-hours time points of the present study), between eight and 16 hours PP (including the 12-hours time point), between 16 and 24 hours PP (corresponding to the 24-hours time point), at two days of age (corresponding to the 48-hours time point), among other age ranges. Thus, our discussion is based on the references of the aforementioned work for most of the blood gas test values.
Blood pH values (Table 5) were similar among the groups in the zero and six-hours time points; however, compared to the $\mathrm{pH}$ values observed in other studies, these presented a tendency towards acidosis (Benesi 1993). This may have occurred because, in the work of Lisboa et al. (2002), the animals evaluated presented a longer life time interval (zero to eight hours), which could allow, in healthy animals, for a compensation of acidosis. It must be noted that the birth causes changes to the blood flow in the uterus and placenta, promoting physiological acidosis with blood $\mathrm{pH}$ values around 7.2 (Benesi 1993, Ravary-Plumioën 2009), similar to that found in the present study. At 24 and 48 hours, the IVF Group showed higher $\mathrm{pH}$ values, which shows a faster corrective response to physiological acidosis. At 48 hours, all three groups presented similar $\mathrm{pH}$ values. It is noteworthy that all groups presented increasing $\mathrm{pH}$ values throughout the study, indicating maturing of the respiratory system and the action of the buffer system in the neonates' organism, in addition to the increase of compensatory HR and RR to maintain homeostasis. 
On the other hand, the $\mathrm{PPCO}_{2}$ (Table 6) was higher than the values found in other studies for the three groups at the initial time points. This is probably due to the same reason presented above: the age range composing the initial group of Lisboa et al. (2002) ranges from the time of birth to eight hours. Thus, the animals had had more time to stabilize breathing and compensate for the physiological acidosis compared to the values found in specimens collected immediately after birth. With regard to the $\mathrm{PPCO}_{2}$, no difference was observed among the groups, except at 48 hours, when the parameter was higher in the AI Group, although it remained within the reference limits. The higher $\mathrm{PPCO}_{2}$ in the AI Group, associated with the faster correction of $\mathrm{pH}$ in the IVF Group, detailed above, can be explained by the management of the farm housing the animals, since the birth of the IVF calves were prematurely assisted with a view to reduce mortality due to difficult deliveries in order to preserve their economic value. That is, even births without dystocia were assisted, which increased their speed. Consequently, the repercussions in the acid-base balance of the animals were milder compared to the calves in the AI Group. In all groups, the $\mathrm{PPCO}_{2}$ values decreased over time, showing respiratory adaptation of the neonates.

The variables $\mathrm{HCO}_{3}$ (Table 7) and $\mathrm{TCO}_{2}$ (Table 8) behaved similarly, in general, as bicarbonate is usually determined by the $\mathrm{TCO}_{2}$ and represents its value, i.e. it is equal to approximately $95 \%$ of the latter total (Carlson \& Bruss 2008). The values at birth were similar among the three groups, while the CA Group presented lower values at 12,24 , and 48 hours. In addition, the means of these parameters were below the values physiologically established until 12 hours in the AI and IVF groups and did not reach the expected values with compensation in the AC Group. Therefore, it is important to note the significance of the metabolic component in determining acidosis in cloned calves compared to the animals in the other study groups. In turn, the values established for the BE variable (Table 9) in neonate bovines are $-1.5 \mathrm{mmol} / \mathrm{L}$ for the lower threshold and about $8 \mathrm{mmol} / \mathrm{L}$ for the upper threshold (Lisboa et al. 2002). At zero hour, the three study groups presented medians below

Table 5. Means and standard deviations for venous blood $\mathrm{pH}(\mathrm{pH})$ in the groups of calves conceived by artificial insemination (AI), in vitro fertilization (IVF), and animal cloning (AC), at the different test time points $(0,6,12,24$, and 48 hours after birth)

\begin{tabular}{|c|c|c|c|c|}
\hline \multirow{2}{*}{ Time points } & \multicolumn{3}{|c|}{$\mathrm{pH}$} & \multirow{2}{*}{$\mathrm{P}$} \\
\hline & $\mathrm{AI}$ & IVF & $\mathrm{AC}$ & \\
\hline T0 & $7.18 \pm 0.12 \mathrm{cA}$ & $7.20 \pm 0.08 \mathrm{cA}$ & $7.20 \pm 0.06 \mathrm{cA}$ & 0.684 \\
\hline T6 & $7.27 \pm 0.07 \mathrm{bA}$ & $7.31 \pm 0.05 \mathrm{bA}$ & $7.28 \pm 0.04 \mathrm{abA}$ & 0.131 \\
\hline $\mathrm{T} 12$ & $7.30 \pm 0.07 \mathrm{abAB}$ & $7.34 \pm 0.02 \mathrm{abA}$ & $7.26 \pm 0.07 \mathrm{bB}$ & 0.002 \\
\hline $\mathrm{T} 24$ & $7.34 \pm 0.06 \mathrm{abB}$ & $7.40 \pm 0.06 \mathrm{aA}$ & $7.28 \pm 0.09 \mathrm{abB}$ & $<0.001$ \\
\hline $\mathrm{T} 48$ & $7.35 \pm 0.06 \mathrm{aA}$ & $7.39 \pm 0.03 \mathrm{aA}$ & $7.34 \pm 0.08 \mathrm{aA}$ & 0.061 \\
\hline $\mathrm{P}$ & $<0.001$ & $<0.001$ & $<0.001$ & \\
\hline
\end{tabular}

$\overline{\mathrm{a}, \mathrm{b}, \mathrm{c}, \mathrm{A}, \mathrm{B}}$ Means followed by the same lower case letter in a column and upper case in a row do not differ significantly by the Tukey test (P>0.05).

Table 6. Means and standard deviations for partial pressure of carbon dioxide $\left(\mathrm{PPCO}_{2}\right)$ in the groups of calves conceived by artificial insemination (AI), in vitro fertilization (IVF), and animal cloning (AC), at the different test time points $(0,6,12,24$, and 48 hours after birth)

\begin{tabular}{ccccc}
\hline \multirow{2}{*}{ Time points } & \multicolumn{3}{c}{$\mathrm{PPCO}_{2}(\mathrm{mmHg})$} & AC \\
\cline { 2 - 4 } & $\mathrm{AI}$ & $\mathrm{IVF}$ & $60.6 \pm 8.3 \mathrm{aA}$ & \\
T0 & $62.3 \pm 9.9 \mathrm{aA}$ & $60.6 \pm 6.2 \mathrm{aA}$ & $52.2 \pm 5.7 \mathrm{bA}$ & 0.785 \\
T6 & $53.5 \pm 10.4 \mathrm{bA}$ & $53.5 \pm 6.2 \mathrm{bA}$ & $50.0 \pm 5.6 \mathrm{bcA}$ & \\
T12 & $53.3 \pm 10.8 \mathrm{bA}$ & $51.7 \pm 5.2 \mathrm{bcA}$ & $49.4 \pm 12.1 \mathrm{bcA}$ & \\
T24 & $51.0 \pm 7.9 \mathrm{bA}$ & $46.3 \pm 5.8 \mathrm{dA}$ & $46.1 \pm 5.7 \mathrm{cB}$ & 0.499 \\
T48 & $53.3 \pm 8.0 \mathrm{bA}$ & $47.8 \pm 3.5 \mathrm{cdB}$ & $<0.001$ & 0.003 \\
P & $<0.001$ & $<0.001$ &
\end{tabular}

$\overline{\mathrm{a}, \mathrm{b}, \mathrm{c}, \mathrm{d}, \mathrm{A}, \mathrm{B}}$ Means followed by the same lower case letter in a column and upper case in a row do not differ significantly by the Tukey test (P>0.05).

Table 7. Means and standard deviations for bicarbonate $\left(\mathrm{HCO}_{3}\right)$ in the groups of calves conceived by artificial insemination (AI), in vitro fertilization (IVF), and animal cloning (AC), at the different test time points $(0,6,12,24$, and 48 hours after birth)

\begin{tabular}{|c|c|c|c|c|}
\hline \multirow{2}{*}{ Time points } & \multicolumn{3}{|c|}{$\mathrm{HCO}_{3}(\mathrm{mmol} / \mathrm{L})$} & \multirow{2}{*}{$\mathrm{P}$} \\
\hline & $\mathrm{AI}$ & IVF & $\mathrm{AC}$ & \\
\hline $\mathrm{T} 0$ & $22.9 \pm 4.5 \mathrm{cA}$ & $23.6 \pm 3.9 \mathrm{bA}$ & $22.9 \pm 2.9 \mathrm{aA}$ & 0.845 \\
\hline $\mathrm{T} 6$ & $24.4 \pm 2.8 \mathrm{bcAB}$ & $26.6 \pm 3.6 \mathrm{aA}$ & $23.9 \pm 2.3 \mathrm{aB}$ & 0.033 \\
\hline $\mathrm{T} 12$ & $25.5 \pm 2.7 \mathrm{bA}$ & $27.7 \pm 3.3 \mathrm{aA}$ & $22.4 \pm 3.7 \mathrm{aB}$ & $<0.001$ \\
\hline $\mathrm{T} 24$ & $26.7 \pm 3.2 \mathrm{abA}$ & $28.0 \pm 1.5 \mathrm{aA}$ & $22.6 \pm 2.6 \mathrm{aB}$ & $<0.001$ \\
\hline $\mathrm{T} 48$ & $29.0 \pm 3.4 \mathrm{aA}$ & $28.4 \pm 1.8 \mathrm{aA}$ & $24.4 \pm 3.3 \mathrm{aB}$ & $<0.001$ \\
\hline $\mathrm{P}$ & $<0.001$ & $<0.001$ & 0.235 & \\
\hline
\end{tabular}

\footnotetext{
$\overline{\mathrm{a}, \mathrm{b}, \mathrm{c}, \mathrm{A}, \mathrm{B}}$ Means followed by the same lower case letter in a column and upper case in a row do not differ significantly by the Tukey test (P>0.05).
} 
$-1.5 \mathrm{mmol} / \mathrm{L}$. The values increased over the PN time; the AI and IVF groups reached the normal range at six hours, while the AC Group presented values under the lower threshold until 48 hours PN, in different ways. Thus, it was once again evident that the AC Group presented insufficient alkaline reserve and higher acidosis than the other groups.
As for $\mathrm{SO}_{2}$ (Table 10) and $\mathrm{PO}_{2}$ (Table 11) values, we observed no differences among the groups seeing that, overall, the changes among groups over the study time would be more faithfully shown in arterial blood samples. The venous blood results did not allow clearer results as they cannot effectively reflect physiological variations (Houpt 2006).

Table 8. Means and standard deviations for total carbon dioxide $\left(\mathrm{TCO}_{2}\right)$ in the groups of calves conceived by artificial insemination (AI), in vitro fertilization (IVF), and animal cloning (AC), at the different test time points

$(0,6,12,24$, and 48 hours after birth)

\begin{tabular}{|c|c|c|c|c|}
\hline \multirow{2}{*}{ Time points } & \multicolumn{3}{|c|}{$\mathrm{TCO}_{2}(\mathrm{mmol} / \mathrm{L})$} & \multirow{2}{*}{$\mathrm{P}$} \\
\hline & $\mathrm{AI}$ & IVF & $\mathrm{AC}$ & \\
\hline T0 & $24.4 \pm 4.4 \mathrm{dA}$ & $25.3 \pm 4.0 \mathrm{bA}$ & $24.5 \pm 3.0 \mathrm{aA}$ & 0.779 \\
\hline T6 & $25.6 \pm 3.2 \mathrm{cdA}$ & $28.0 \pm 3.8 \mathrm{abA}$ & $25.4 \pm 2.4 \mathrm{aA}$ & 0.053 \\
\hline $\mathrm{T} 12$ & $27.0 \pm 2.7 \mathrm{bcA}$ & $28.9 \pm 3.6 \mathrm{aA}$ & $23.7 \pm 3.9 \mathrm{aB}$ & $<0.001$ \\
\hline $\mathrm{T} 24$ & $28.0 \pm 3.3 \mathrm{bA}$ & $29.4 \pm 1.5 \mathrm{aA}$ & $24.2 \pm 2.8 \mathrm{aB}$ & $<0.001$ \\
\hline $\mathrm{T} 48$ & $30.5 \pm 3.7 \mathrm{aA}$ & $29.6 \pm 2.1 \mathrm{aA}$ & $25.6 \pm 3.2 \mathrm{aB}$ & $<0.001$ \\
\hline $\mathrm{P}$ & $<0.001$ & $<0.001$ & 0.337 & \\
\hline
\end{tabular}

$\overline{\mathrm{a}, \mathrm{b}, \mathrm{c}, \mathrm{d}, \mathrm{A}, \mathrm{B}}$ Means followed by the same lower case letter in a column and upper case in a row do not differ significantly by the Tukey test (P>0.05).

Table 9. Medians, first and third percentiles obtained for base excess (BE) in the groups of calves conceived by artificial insemination (AI), in vitro fertilization (IVF), and animal cloning (AC), at the different test time points

$(0,6,12,24$, and 48 hours after birth)

\begin{tabular}{|c|c|c|c|c|}
\hline \multirow{2}{*}{ Time points } & \multicolumn{3}{|c|}{$\mathrm{BE}(\mathrm{mmol} / \mathrm{L})$} & \multirow{2}{*}{$\mathrm{P}$} \\
\hline & AI & IVF & $\mathrm{AC}$ & \\
\hline T0 & $-5.0(-9.0--1.5) \mathrm{cA}$ & $-3.0(-5.0--1.0) b A$ & $-6.0(-6.8--1.8) \mathrm{aA}$ & 0.466 \\
\hline T6 & $-3.0(-4.0-0.0) \mathrm{cA}$ & $-1.0(-2.0-4.5) \mathrm{abA}$ & $-3.0(-4.8--1.0) \mathrm{aA}$ & 0.053 \\
\hline $\mathrm{T} 12$ & $0.0(-2.5-1.5) \mathrm{bcAB}$ & $2.0(0.0-2.0) \mathrm{aA}$ & $-5.0(-6.0-0.0) \mathrm{aB}$ & $<0.001$ \\
\hline $\mathrm{T} 24$ & $2.0(0.0-4.0) \mathrm{abA}$ & $4.0(3.0-4.8) \mathrm{aA}$ & $-5.0(-6.5--2.0 \mathrm{aB}$ & $<0.001$ \\
\hline $\mathrm{T} 48$ & $3.5(2.0-7.0) \mathrm{aA}$ & $4.0(2.0-6.0) \mathrm{aA}$ & $-2.0(-4.8-4.0) a B$ & 0.004 \\
\hline $\mathrm{P}$ & $<0.001$ & $<0.001$ & 0.240 & \\
\hline
\end{tabular}

$\overline{\mathrm{a}, \mathrm{b}, \mathrm{c}, \mathrm{A}, \mathrm{B}}$ Means followed by the same lower case letter in a column and upper case in a row do not differ significantly by the Tukey test (P>0.05).

Table 10. Means and standard deviations for oxygen saturation $\left(\mathrm{SO}_{2}\right)$ in the groups of calves conceived by artificial insemination (AI), in vitro fertilization (IVF), and animal cloning (AC), at the different test time points

$(0,6,12,24$, and 48 hours after birth)

\begin{tabular}{|c|c|c|c|c|}
\hline \multirow{2}{*}{ Time points } & \multicolumn{3}{|c|}{$\mathrm{SO}_{2}(\%)$} & \multirow{2}{*}{$\mathrm{P}$} \\
\hline & $\mathrm{AI}$ & IVF & $\mathrm{AC}$ & \\
\hline T0 & $25.8 \pm 11.8 \mathrm{bA}$ & $24.0 \pm 6.7 \mathrm{cA}$ & $20.7 \pm 4.0 \mathrm{bA}$ & 0.234 \\
\hline T6 & $31.3 \pm 10.1 \mathrm{abA}$ & $27.7 \pm 10.1 \mathrm{bcA}$ & $25.5 \pm 7.3 \mathrm{abA}$ & 0.193 \\
\hline $\mathrm{T} 12$ & $32.2 \pm 12.2 \mathrm{abA}$ & $31.0 \pm 8.8 \mathrm{bcA}$ & $28.4 \pm 11.7 \mathrm{aA}$ & 0.599 \\
\hline $\mathrm{T} 24$ & $36.2 \pm 12.3 \mathrm{aA}$ & $38.9 \pm 13.9 \mathrm{abA}$ & $28.0 \pm 11.3 \mathrm{abA}$ & 0.053 \\
\hline $\mathrm{T} 48$ & $33.3 \pm 10.0 \mathrm{abB}$ & $42.9 \pm 13.8 \mathrm{aA}$ & $27.3 \pm 5.6 \mathrm{abB}$ & $<0.001$ \\
\hline $\mathrm{P}$ & 0.008 & $<0.001$ & 0.040 & \\
\hline
\end{tabular}

$\overline{\mathrm{a}, \mathrm{b}, \mathrm{c}, \mathrm{A}, \mathrm{B}}$ Means followed by the same lower case letter in a column and upper case in a row do not differ significantly by the Tukey test (P>0.05).

Table 11. Means and standard deviations for partial pressure of oxygen ( $\left.\mathrm{PPO}_{2}\right)$ in the groups of calves conceived by artificial insemination (AI), in vitro fertilization (IVF), and animal cloning (AC), at the different test time points

$(0,6,12,24$, and 48 hours after birth)

\begin{tabular}{|c|c|c|c|c|}
\hline \multirow{2}{*}{ Time points } & \multicolumn{3}{|c|}{$\mathrm{PPO}_{2}(\mathrm{mmHg})$} & \multirow{2}{*}{$\mathrm{P}$} \\
\hline & $\mathrm{AI}$ & IVF & $\mathrm{AC}$ & \\
\hline T0 & $23.95 \pm 6.28 \mathrm{aA}$ & $23.07 \pm 3.26 \mathrm{bA}$ & $21.60 \pm 2.69 \mathrm{aA}$ & 0.336 \\
\hline $\mathrm{T} 6$ & $23.65 \pm 4.65 \mathrm{aA}$ & $22.33 \pm 3.90 \mathrm{bA}$ & $21.47 \pm 4.02 \mathrm{aA}$ & 0.319 \\
\hline $\mathrm{T} 12$ & $23.70 \pm 4.54 \mathrm{aA}$ & $22.93 \pm 3.60 \mathrm{bA}$ & $22.73 \pm 5.39 \mathrm{aA}$ & 0.801 \\
\hline $\mathrm{T} 24$ & $25.15 \pm 5.20 \mathrm{aA}$ & $24.87 \pm 5.08 \mathrm{abA}$ & $22.47 \pm 6.77 \mathrm{aA}$ & 0.349 \\
\hline $\mathrm{T} 48$ & $23.35 \pm 4.20 \mathrm{aB}$ & $28.13 \pm 5.90 \mathrm{aA}$ & $21.33 \pm 3.44 \mathrm{aB}$ & $<0.001$ \\
\hline $\mathrm{P}$ & 0.645 & 0.004 & 0.799 & \\
\hline
\end{tabular}

$\overline{\mathrm{a}, \mathrm{b}, \mathrm{A}, \mathrm{B}}$ Means followed by the same lower case letter in a column and upper case in a row do not differ significantly by the Tukey test (P $>0.05$ ). 


\section{CONCLUSIONS}

We conclude that, particularly in cloned calves, PP acidosis was more accentuated than the physiological acidosis expected for neonates, especially with regard to the metabolic component notable in the $\mathrm{HCO}_{3}^{-}, \mathrm{TCO}_{2}$, and $\mathrm{BE}$ changes compared to the other groups. This imbalance reflected in a lower Apgar score and higher heart and respiratory rate in the AC Group.

The animals conceived by IVF did not present changes beyond the expected for newborn animals, similar to the ones presented by the AI Group. Therefore, this study confirms the need for intensive follow-up of newborn clones to allow for early diagnosis and proper treatment of this condition, seeing that it took them over 24 hours to overcome the physiological acidosis expected for bovine neonates.

Acknowledgments. The authors would like to thank FMVZ-Unesp, Botucatu/SP for the infrastructure and equipment used in this experiment; FAPESP (Fundação de Amparo à Pesquisa do Estado de São Paulo), for the $\mathrm{PhD}$ fellowship (Process 2014/26041-8); and the farms Agrindus (Descalvado/SP), Passoca (Santa Rita de Caldas/MG), and In Vitro Brasil - clonagem animal (Mogi-Mirim/SP) for lending the animals evaluated.

Conflict of interest statement.- The authors have no competing interests.

\section{REFERENCES}

Benesi F.J. 1993. Síndrome da asfixia neonatal dos bezerros: importância e avaliação crítica. Arqs Esc. Med. Vet. 16:38-48.

Birgel Junior E.H., Meirelles F.V., Maiorka P.C., Kubrusly F.S. \& Ollhoff R.D. 2011. Medicina interna de bezerros clonados: distúrbios clínicos observados nos primeiros 30 dias de vida. Revta Educ. Contin. Med. Vet. Zootec. 9(1):24-31.

Bleul U. 2009. Respiratory distress syndrome in calves. Vet. Clin. N. Am., Food Anim. Pract. 25(1):179-193. <http://dx.doi.org/10.1016/j.cvfa.2008.10.002> $<$ PMid:19174288>

Born E. 1981. Untersuchungen über den Einfluss der Schnittentbindung auf die Vitalität neugeborener Kälber. Master's Thesis, Tierärztliche Hochschule, Hannover. 47p.

Carlson G.P. \& Bruss M. 2008. Fluid, electrolyte and acid-base balance, p.529559. In: Kaneko J.J. (Ed), Clinical Biochemistry of Domestic Animals. 6th ed. Academic Press, San Diego. <http://dx.doi.org/10.1016/B978-0-12370491-7.00017-9>.

Dantas G.N. 2015. Maturidade pulmonar e fetal de bezerros da raça holandesa preta e branca recém-nascidos, a termo e hígidos: análise do líquido amniótico. Master's Thesis, Faculdade de Medicina Veterinária e Zootecnia, Unesp, Botucatu. 67p.

DiBartola S.P. 1992. Fluid Therapy in Small Animal Practice. W.B. Saunders, Philadelphia. 720p.

Feitosa F.L.F. \& Benesi F.J. 2014. Semiologia de recém-nascidos ruminantes e equídeos, p.69-97. In: Ibid. (Eds), Semiologia Veterinária. Vol.1. 3aㅡ ed. Roca, São Paulo.

Gasparelli E.R.F. 2007. Determinação da atividade sérica de enzimas hepáticas e da concentração de ureia, creatinina, cortisol, imunoglobulina G e dos valores hemogasométricos de bezerros da raça nelore oriundos de fertilização in vivo e fertilização in vitro. Master's Thesis, Faculdade de Odontologia e Curso de Medicina Veterinária de Araçatuba, Unesp, Botucatu. 74p.

Houpt T.R. 2006. Equilíbrio ácido-básico, p.147-160. In: Reece W.O. (Ed.), Dukes, Fisiologia dos Animais Domésticos. 12ª ed. Guanabara Koogan, Rio de Janeiro.

Lisboa J.A.N., Benesi F.J., Leal M.L.R. \& Teixeira C.M.C. 2002. Efeito da idade sobre o equilíbrio ácido-básico de bezerras sadias no primeiro mês de vida. Braz. J. Vet. Res. Anim. Sci. 39(3):136-142. <http://dx.doi.org/10.1590/ S1413-95962002000300005>

Lisboa J.A.N., Benesi F.J., Leal M.L.R. \& Teixeira C.M.C. 2003. Temperatura retal e frequências respiratória e cardíaca de bezerras sadias no primeiro mês de vida. Vet. Notícias 9(2):83-89.

Mee J.F. 2008. Prevalence and risk factors for distocia in dairy cattle: a review. Vet. J. 176(1):93-101. <http://dx.doi.org/10.1016/j.tvjl.2007.12.032> $<$ PMid:18328750>

Piccione G., Costa A., Bertolucci C., Borruso M., Pennisi P. \& Caola G. 2006. Acid-base balance modifications in the lamb and goat kids during the first week of life. Small Rumin. Res. 63(3):304-308. <http://dx.doi.org/10.1016/j. smallrumres.2005.02.022>

Pimenta-Oliveira A., Oliveira-Filho J.P., Dias A. \& Gonçalves R.C. 2011. Morbidity-mortality and performance evaluation of Brahman calves from in vitro embryo production. BMC Vet. Res. 7(1):79-80. <http://dx.doi. org/10.1186/1746-6148-7-79><PMid:22136315>

Ravary-Plumioën B. 2009. Resuscitation procedures and life support of the newborn calf. Revue Méd. Vét. 160(8/9):410-419.

Sucupira M.C.A. \& Ortolani E.L. 2003. Uso de sangue arterial e venoso no exame do equilíbrio ácido-básico de novilhos normais ou com acidose metabólica. Ciência Rural 33(5):863-868. <http://dx.doi.org/10.1590/ S0103-84782003000500011>

Vaala W.E. \& House J.K. 2006. Adaptação, asfixia e reanimação perinatais, p.266-276. In: Smith B.P. (Ed.), Medicina Interna de Grandes Animais. 3a ed. Manole, Barueri. 1728p. 